
\title{
25 Research Square \\ Unity in Diversity - Food Plants and Fungi of Sakartvelo (Republic of Georgia), Caucasus
}

Rainer W Bussmann ( $\square$ rainer.bussmann@iliauni.edu.ge )

Ilia State University https://orcid.org/0000-0002-3524-5273

\section{Narel Y Paniagua Zambrana}

Ilia State University

Inayat Ur Rahman

Hazara University

\section{Zaal Kikvidze}

Ilia State University

Shalva Sikharulidze

Ilia State University

David Kikodze

Ilia State University

David Tchelidze

Ilia State University

Manana Khutsishvili

Ilia State University

Ketevan Batsatsashvili

Ilia State University

\section{Research Article}

Keywords: Republic of Georgia, Caucasus, Traditional Knowledge, Knowledge loss, Food plants, Conservation

Posted Date: August 4th, 2021

DOl: https://doi.org/10.21203/rs.3.rs-753320/v1

License: (9) This work is licensed under a Creative Commons Attribution 4.0 International License.

Read Full License

Version of Record: A version of this preprint was published at Journal of Ethnobiology and Ethnomedicine on December 1st, 2021. See the published version at https://doi.org/10.1186/s13002-021- 
00490-9.

Page 2/31 


\section{Abstract}

Background: The Republic of Georgia is part of the Caucasus biodiversity hotspot, and human agricultural plant use dates bat at least 6000 years. Over the last years lots of ethnobotanical research on the area has been published. In this paper we analyze the use of food plants in the $80 \%$ of Georgia not occupied by Russian forces. We hypothesized that, (1) given the long tradition of plant use, and the isolation under Soviet rule, plant use both based on home gardens and wild harvesting would be more pronounced in Georgia than in the wider region, (2) food plant use knowledge would be widely and equally spread in most of Georgia, (3) there would still be incidence of knowledge loss despite wide plant use, especially in climatically favored agricultural regions in Western and Eastern Georgia.

Methods: From 2013 to 2019 we interviewed over 380 participants in all regions of Georgia not occupied by Russian forces and recorded over 19800 mentions of food plants. All interviews were carried out in the participants' homes and gardens by native speakers of Georgian and its dialects (Imeretian, Rachian, Lechkhumian, Tush, Khevsurian, Psavian, Kakhetian), other Kartvelian languages (Megrelian, Svan) and minority languages (Ossetian, Ude, Azeri, Armenian, Greek).

Results: The regional division was based primarily on historic provinces of Georgia, which often coincides with the current administrative borders. The total number of taxa, mostly identified to species, was 474 . Taxonomically, the difference between two food plant groups - garden versus wild - was strongly pronounced even at family level. The richness of plant families was 66 versus 97 families in garden versus wild plants, respectively, and the difference was highly significant. Other diversity indices also unequivocally pointed to considerably more diverse family composition of wild versus garden plants as the differences between all the tested diversity indices appeared to be highly significant.

Conclusions: Relationships among the regions in the case of wild food plants show a different and clearer pattern. In particular, adjacent regions cluster together (Kvemo Zemo Racha, and Zemo Imereti; Samegrelo, Guria, Adjara, Lechkhumi and Kvemo and Zemo Svaneti; Meskheti, Javakheti, Kvemo Kartli; Mtianeti, Kakheti, Khevsureti, Tusheti. Like in the case of the garden food plants, species diversity of wild food plants mentioned varied strongly. Climate severity and traditions of the use of wild food plants might play role in this variation. Overall food plant knowledge is widely spread all across Georgia, and broadly maintained

\section{Background}

Georgia is situated between latitudes $41^{\circ}$ and $44^{\circ} \mathrm{N}$, and longitudes $40^{\circ}$ and $47^{\circ} \mathrm{E}$, with an area of 69700 $\mathrm{km}^{2}$, with $20 \%$ of the country currently occupied by Russian forces (Fig. 1). Georgia politically associates with European Union and takes part in all major programs of European development and cooperation. Georgia can be defined as a transcontinental country on the divide between Asia and Europe, with its larger part located south to this divide (i.e., in Asia) and smaller but strategically important parts (Khevi, Piriketi Khevsureti, etc.) located north of the continent divide (i.e., in Europe) [1]. 
The uplift of the Georgian Caucasus started in the late Oligocene and shares the same structural characteristics as the younger mountains of Europe. The Greater Caucasus mostly includes Cretaceous and Jurassic rocks, interspersed with Paleozoic and Precambrian formations in higher regions. Hard, crystalline, metamorphosed rocks like schist and gneisses, as well as pre-Jurassic granites are found in the western part, while softer, Early and Middle Jurassic clayey schist and sandstones in the eastern part. The foots of the Greater Caucasus are built of younger limestone, sandstones, and marls. The Lesser Caucasus in contrast is predominantly formed of Paleogene rocks interspersed with Jurassic and Cretaceous formations. The youngest geological structures of Georgia are represented by the vast volcanic plateaus in the southern part of country. These divisions lead to an extremely complex terrain with pronounced climatic gradients: (1) the mountains of the greater Caucasus with peaks over $5000 \mathrm{~m}$ (Shkara, Babis Mta, Chanchakhi, etc.); (2) the inter-mountain plains between the Greater and Lesser Caucasus mountains; (3) the mountains of the Lesser Caucasus with peaks rarely exceeding $3000 \mathrm{~m}$ (Mepistskaro, Kheva, Shavi KIde, Kanis Mta, Arsiani); (4) the Volcanic plateau of the Southern Georgia with elevations from 1300-2200 m. [2-4].

Georgia's climate is influenced by its location in the warm temperate zone stretching from the Black to the Caspian Seas, and the complexity of its terrain. Georgia has a coastline of $330 \mathrm{~km}$ with warm climate, the mean temperature reaching $4-7^{\circ} \mathrm{C}$ in January and $22-23^{\circ} \mathrm{C}$ in July, and high precipitation $(1500-2000$ $\mathrm{mm}$ annually). The warm oceanic-subtropical climate can be found only at lower elevations (less than $650 \mathrm{~m}$ ); in more elevated terrains and also to the north and east the climate becomes moderately warm. The Greater Caucasus bars cold air from the north, while warm and moist air from the Black Sea spreads easily into the coastal lowlands until reaching the Likhi range, which partly impedes further westward movement of the warm and moist air. In central Georgia precipitation in mountains can be twice that in the plains. In the mountains weather conditions change to cool and wet quite steeply with increasing elevation and above $2100 \mathrm{~m}$ the environment becomes sub-alpine and alpine; permanent snow and ice above $3600 \mathrm{~m}[2-4]$.

\section{Plant use history}

The Caucasus is regarded as global biodiversity hotspot [5-8]. Botanical has a long history, and the vegetation composition as well as flora are well known [2-3].

The territory of modern-day Georgia (Fig. 1) has been inhabited since the early Stone Age, and agriculture was already well developed during the early Neolithic [9], although human occupation started already in the Early Pleistocene, with the 1.7-Myr-old hominid fossils of Dmanisi in Southern Georgia being the earliest known hominid-site outside of Africa [10-12]. The history of plant and animal use has been documented since the Upper Paleolithic through fossils found in Dzudzuana Cave, dated to $36-34 \mathrm{Ka}$ BP, including wool (Capra caucasica), and dyed fibers of wild flax (Linum usitatissimum) [13]. Archaeological findings from the Neolithic and Early Bronze periods dating back to the 6th - 2nd millennium BC are rich with plant fossils and seeds of both wild species and local landraces [14]. The earliest seeds of Vitis vinifera (grapevine) were excavated in southern Georgia and date to about 8000 
years BP [15]. Medicinal species like Alchemilla millefolium, Artemisia annua, A. absinthium, Centaurea jacea and Urtica dioica found in the archaeological record are still used in the modern pharmacopoeia [16].

Due to its ancient roots agriculture in Georgia is characterized by a great diversity of landraces, and endemic species of crops, already documented in Soviet times [17-21]. However, starting with the implementation of Stalinist agricultural reforms in the 1950s, a rapid loss of local cultivars occurred [2225]. This process accelerated during post-independence, and knowledge loss has been shown to even extent to aggravate wolf-human conflicts [26]. However, a wide variety of local cultivars can still be found in case of Vitis vinifera (Vitaceae) shows its highest genetic diversity in Georgia, with over 600 varieties known, and several dozen used commercially $[9,15,27-30]$. In contrast, essentially none of the 144 varieties, and 150 forms of wheat (Triticum) registered in Georgia in the 1940s [20-21] are sown in modern Georgian commercial agriculture [24], although traditional varieties are still reported from nearby Turkey [31]. The situation is similar in case of Hordeum vulgare (Poaceae) which originally was important in beer production, for religious rituals and traditional medicine [9, 32] and Secale cereale (Poaceae) [33].

In contrast to the loss of cereals, legumes like peas (Pisum sativum), lentils (Lens cornicularis), chickpeas (Cicer arietinum), faba beans (Vicia faba), and vegetables like garden lettuce (Lactuca sativa), beans (Phaseolus vulgaris), basil (Ocimum basilicum), peppermint (Mentha x piperita), onions (Allium cepa), sugar beets (Beta vulgaris), spinach (Spinaca oleracea), carrots (Daucus carota), radishes (Raphanus sativus), turnips (Brassica rapa var. rapa), welsh onion (Allium fistulosum), amaranth (Amaranthus viridis), goosefoot (Chenopodium album), leeks (Allium apeloprasum) and garlic (Allium sativum) are still common in home gardens. Herbs like parsley (Petroselinum crispum), coriander (Coriandrum sativum), tarragon (Artemisia dracunculus), savory (Satureja hortensis), garden cress (Lepidium sativum), dill (Anethum graveolens), fennel (Foeniculum vulgare), celery (Apium dulce), and Allium fistulosum (Chinese onion are widely cultivated and popular ingredients of local cuisine [1]. The maintenance of such diversity is of high importance as source material for global crop production [34-35]. Many species are widely sold as medicines [36].

Over the last years, ethnobotanical research in Georgia has received a large boost, and a wide variety of studies on all aspects of plant use have been published [37-51]. Few of these however focused entirely of food plants [37, 51], many of which are still cultivated in small home-gardens. Home-gardens are often cited as important reservoirs for crop germplasm [52-57] and are mostly sources of food [58-59]. In wider Eurasia, home gardens have been shown to be an important repository of plant diversity are often part of complex seed exchange networks [60-63].

Given the trajectory of ethnobotanical studies in Georgia, a meta-analysis of the data food plant uses was long overdue. In this publication we hypothesized that, (1) given the long tradition of plant use, and the isolation under Soviet rule, plant use both based on home gardens and wild harvesting would be more pronounced in Georgia than in the wider region, (2) food plant use knowledge would be widely and 
equally spread in most of Georgia, (3) there would still be incidence of knowledge loss despite wide plant use, especially in climatically favored agricultural regions in Western and Eastern Georgia.

\section{Materials And Methods}

\section{Ethnobotanical interviews}

From 2013 to 2019 we interviewed over 380 participants in all regions of Georgia not occupied by Russian forces and recorded over 19800 mentions of food plants. Interviews using semi-structured questionnaires were conducted after obtaining the oral prior informed consent of the participants, which were selected by snowball sampling, trying to reach gender balance and representing different agegroups (13-93 years). Most participants were however over 50 years old, as interviews targeted remote villages where only very few younger people remain. All interviews were carried out in the participants' homes and gardens by native speakers of Georgian and its dialects (Imeretian, Rachian, Lechkhumian, Tush, Khevsurian, Psavian, Kakhetian), other Kartvelian languages (Megrelian, Svan) and minority languages (Ossetian, Ude, Azeri, Armenian, Greek). Interviews were subsequently translated into English. Plants grown in the home gardens were used as prompts, while wild-collected species were free listed. In contrast to many other countries Georgia benefits from a complete flora [64-68] and a broad inventory of vernacular names in all languages [67]. Species were identified directly in the field, using this literature, and vouchers collected and deposited in the National Herbarium of Georgia (TBI). The nomenclature of all species follows www.tropicos.org, under APGIII [69]. Collection permits were provided through the Institute of Botany, llia State University, Tbilisi.

\section{Data analysis}

Data were tabulated in an usual way using excel sheets and a combined matrix was constructed with plant entries in rows and plant data in columns including date, place, participant's age and gender, interviewer, plant identity (Latin, Georgian vernacular, local names), the use category, which parts were used, and the source (garden or forest). We compared species diversity among groups of species (forest versus garden, various provinces) using sample-based rarefaction as well as widely used diversity indices: Dominance $(D)$, Shannon $(H)$, Evenness $\left(e^{\wedge} H / S\right)$, Simpson index, $(1-D)$, Equitability $(\mathcal{C})$, Fisher alpha, Berger-Parker (BP). Similarity of species composition among groups of plants were analyzed using non-Metric Multi-Dimensional Scaling (nMDS). All these analyses were performed using software PAST4.02 [70].

Test if the usage of plants based on family and genus, plant system used, and general and specific plant parts differ between regions and different altitudinal ranges. I predict that these components will be different, since there will be a different plant composition among regions and along an altitudinal gradient, and that different human communities have their own ethnobotany knowledge, even though they are from the same country. 
We compared the usage of plants based on their (i) family and (ii) genus, (iii) system (root, shoot, or both), and (iv) general (vegetative, reproductive, or both) and (v) more specific (bark, branches, buds, bulb, cones, flowers, fruit, latex, leaves, resin, roots, seeds, shoots, silk, stem, timber, tuber, whole plant) parts used between regions and altitudinal ranges. We also compared (vi) for what purpose plants are used between regions and altitudinal ranges. We removed from our analyses any data that was not possible to make any further identification, such as plants identification above family, and uncertain plant parts. We also removed fungi from our analyses, and samples in which we had no more details about the purpose of usage of plants, i.e., in cases where plants were used as human food, but we did not know exactly for which kind of food. We considered regions and five altitudinal ranges $(0-500 \mathrm{~m}, 501-1000 \mathrm{~m}, 1001-1500 \mathrm{~m}$, 1501-2000m, 2001-2500m) as factors within our ordinations. We conducted non-Metric Multidimensional Scaling (NMDS) followed by a Permutational Multivariate Analysis of Variance (PERMANOVA) with Euclidean distance and 999 permutations using the "RVAideMemoire" package [71].

\section{Results}

The total number of taxa, mostly identified to species, was 554 (Table 1, Appendix Tables 1-3), 96 of which were fungi. Taxonomically, the difference between two food plant groups - garden versus wild was strongly pronounced even at family level (Fig. 2). Only one plant species was bought in markets; some plants were found both in wild and garden (189 mentions, less than 1\%). The great majority of mentions ( $>99 \%$ ) were either from families found either in gardens $(62 \%)$ or wild $(37 \%)$. Over $41 \%$ of all mentions refereed to the use of fruits, $21 \%$ to leaves, about $7 \%$ to seeds, and $5 \%$ to fruiting bodies, leaves/stems and stems. Whole plants were only used very infrequently. Of all families Rosaceae, Apiaceae, Lamiaceae, Amaryllidaceae and Solanaceae showed highest importance. At a generic level, Allium, Pyrus, Malus and Brassica received the highest number of use report. Only 30 species $(6 \%$ of the total) represented $46 \%$ of all use mentions, but only Malus orientalis (3.5\%), Pyrus communis (3.2\%), and Vitis vinifera $(2.7 \%)$ had over $2 \%$ of mentions, and Chenopodium album and Urtica dioica were the only not cultivated plants reaching over $1 \%$ of mentions. In most regions at all altitudinal ranges the aboveground parts were mist frequently used (Fig. 3),

Most plants (65\%) were simply eaten, many either raw (55\%), or fried (e.g. $8 \%$ that were fungi). A full $5 \%$ of all mentioned plant-uses were for pickles (often stems), and a full $18 \%$ of all use reports were for Phkhali (boiled herb pie, especially in spring), and $4 \%$ were used as spices, and around $2 \%$ for the distillation of alcohol. All other use categories (35) had much fewer mentions.

The richness of plant families was 66 versus 97 families in garden and wild plants, respectively, and the difference was highly significant (Fig. 4). Other diversity indices also unequivocally pointed to a considerably more diverse family composition of wild versus garden plants as the differences between all the tested diversity indices appeared to be highly significant (Table 2).

The regions of Georgia can be divided into three groups by the similarity of garden food plants as can be seen on the nMDS ordination graph (Fig. 5). This ordination seems to be influenced on the presence of 
large markets: Adjara, Samegrelo, Guria, and Kakheti which are lowland regions with large cities are joined by minimum distance versus Tori, Zemo Svaneti, Khevsureti, Tusheti and Javakheti, which are the most remote places. Kvemo Svaneti, Lechkhumi, Meskheti, Kvemo Kartli, Zemo Imereti, Zemo and Kvemo Racha, Mtianeti are moderately remote from large markets. The grouping of the regions closer to large markets might however have another distinct reason: Adjara, Samegrelo, Guria, and Kakheti are also the climatically warmest regions in Georgia, with the longest growing seasons. This allows the production of food plants almost all year round, and greatly reduces the dependency on foraging wild species.

For comparison we assessedthe usage of plants between regions based on their family, genus, specific parts used (root, shoot, or both) used, reproductive stages used (vegetative, reproductive, or both) and their specific parts used (bark, branches, buds, bulb, cones, flowers, fruit, latex, leaves, resin, roots, seeds, shoots, silk, stem, timber, tuber, whole plant), but at regional level and within different altitudinal ranges through Non-Multidimensional Scaling (NMDS) followed by Permutational Multivariate Analysis of Variance (PERMANOVA) with 999 permutations and Euclidian distance. The detailed results are depicted in Table 3 and Appendix Tables 4-9.

At the same time, the regions vary strongly in their species richness (Fig. 6). These differences also might reflect the remoteness from large markets and severity of local climate. At this stage we however still have limited data to exactly explain the variation in garden species across the regions, this question requires further study.

Relationships among the regions in the case of wild food plants show a different and clearer pattern (Fig. 7). In particular, adjacent regions cluster together (Kvemo Zemo Racha, and Zemo Imereti; Samegrelo, Guria, Adjara, Lechkhumi and Kvemo and Zemo Svaneti; Meskheti, Javakheti, Kvemo Kartli; Mtianeti, Kakheti, Khevsureti, Tusheti). Like in the case of the garden food plants, species diversity of the wild food plants mentioned varied strongly (Fig. 8). Climate severity and traditions of the use of wild food plants might play role in this variation.

\section{Pkhali and Pickles - emblematic foods of the Caucasus}

Of all food preparations the use of plants as ingredient of boiled herb preparations (mostly

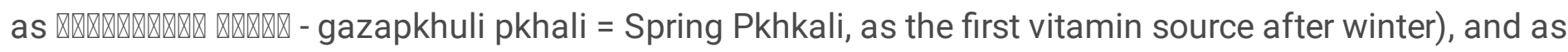
lacto-fermented or vinegar-based pickles are probably the most emblematic ones in the Caucasus, given that almost $50 \%$ of all food mentions were for phkhali, and almost $12 \%$ for pickled plants, and $8 \%$ for teas.

While the overall distribution of families, genera and their uses were similar between regions, although overall most species were used in Guria. However, the knowledge distribution was most uneven for these food categories (Fig. 9). The altitudinal range between $1001-1500 \mathrm{~m}$, followed by $1501-2000 \mathrm{~m}$ were clearly predominant when it came to diversity of plants used as well as uses (Fig. 10). This very unequal distribution of the most important families/genera, as well as their respective uses is reflected in Fig. 11. 
Only $60 \%$ of participants reported making pickles. Of these, over $16 \%$ each came from Zemo Imereti and Khevsureti, and $12 \%$ each from Zvemo Svaneti, the Javakheti-Plateau, and Guria. The first regions represent all high altitude - short growing season areas, where the population does need to preserve food for winter. Guria is relatively warm - but very wet and snow-rich, which also might explain the prevalence of pickles. No participants whatsoever from Adjara, Samegrelo (the most subtropical regions) and Mtianeti (close to the capital Tbilisi) reported making pickles. Unsurprising, Kakhetians were also not enthusiastic about this form of preparation, because Kahketi is also a region famous for its large agricultural production. In contrast, in Tori and Tusheti there are simply less products that actually can be pickled. Preferred species (of a total of 79) for pickles were mostly Amaranthaceae (Amaranthus, Chenopdium), Apiaceae (especially the stems of Anthriscus, Chaerophyllum and Heracleum were pickled, but also, astonishingly, stems of Conium maculatum), Amaryllidaceae (all Allium species), And Polygonaceae (Polygonum and Rumex). In addition, Aruncus vulgaris (Rosceae), Stapyllea colchica (Staphyleaceae). All of these were more important as pickles than "traditional European style species (Cucumis sativus, Capsicum etc.). The fermentation of the ferns Mattheucia struthiopteris (Onocleaceae) and Dryopteris filix-mas (Dryopteridaceae) was similar to what we observed e.g. in the Himalayas.

In case of Pkhali, over $93 \%$ of all participants - from all regions - reported to use such boiled herbs, normally in Spring. This was surprising, as we had expected much more limited use in the climatically favorable regions. Nevertheless, Zemo Imereti (19\% of all Phkhali preparations), Tori and Kvemo Racha (16\% each), Tusheti (15\%) and Khevsureti (14\%) - all mountain regions with long winters, stood out as the real "herb eater" areas. In contrast to the pickled species, essentially only young leaves were used for pkhali, with great emphasis on the same families indicated in pickles. (all pickled plant species were also used for phkhali). The overall number of species fused or pkhali was however much higher (197). The elaboration of phkhali often involves many steps in order to reduce the toxicity of species used, and in most cases a wide variety of herbs are included in each preparation. Interesting examples for the use of toxic species included the leaves of Solanum tuberosum, Veratrum lobelianum and Viola sp.

\section{Discussion}

The use of food plant in Georgia, while varied showed distinct overlap with other studies. However, the number of food plant species used - both cultivated and foraged in this rather small territory - was far higher than in most published studies from either wider region or the Mediterranean and Eurasia [72107]. Interestingly, even studied conducted in pastoralist cultures well known for their use of wild foraged plants for food, e.g. in relatively close-by Kurdistan [108-109], and Turkey [110] showed a much more limited use of plants for food, even when not considering the $20 \%$ of taxa found in Georgia that were fungi. In many areas of the same cultural space, e.g. Dagestan [111], Azerbaijan [112-113] and Amenia [114] the use of wild plants for food has been shown as in steep decline, although a strong signature of food plant use could still be found in markets of the Armenian capital Yerevan [115].

\section{Conclusions}


This study reported on 474 plant and fungal taxa used in Georgia as food. As many mountain regions all over the world, the rural areas of the Georgian Caucasus have suffered a constant population decline for decades, due to harsh economic conditions and lack of modern infrastructure [1, 23, 116-119]. While This has greatly accelerated the loss of traditional agricultural practices, it seems to have affected the use of wild gathered food plants as well as species grown in home gardens to a much more limited extent in Georgia. The home gardens in Georgia clearly continue serving as socio-ecological memory, and an irreplaceable part of Georgian culture, rather than a the widely growing popularity of gardening and foraging found all over Europe [120]. The great variety of food plant species used in the Georgian Caucasus provides a reservoir for food security for the region, as well as a source of important food plant germplasm for international agriculture. This greatly underlines the importance of Georgia as an ancient center of crop domestication and diversification, making Georgia clearly one of the most diverse food plant cultures in wider Eurasia, and the center of what we would like to coin as "Caucasus - Asia Minor Balkans cultural complex".

\section{Declarations}

\section{Acknowledgments}

The authors thank all participants for their generous hospitality and friendship. We are hopeful that this and sub-sequent work in the area will help the communities meet their needs and aspirations.

\section{Ethics statement}

Before conducting interviews, prior informed consent was obtained from all participants. No further permits or ethics approval were required.

\section{Consent for publication}

This manuscript does not contain any individual person's data and further consent for publication is not required.

\section{Availability of data and materials}

The raw data contain the names of all participants and cannot be shared in this form.

\section{Funding}

This study was funded through Saving Knowledge funds. The funding body itself has no direct role in the design of the study, collection or analysis of the data and use of results.

\section{Author contributions}

RWB, NYPZ, SS, ZK, DK, MK, DT, and KB designed the study; RWB, NYPZ, SS, ZK, DT, MK, and KB conducted the fieldwork, ZK and IUR conducted the main statistical analysis; RBU, NYPZ, and ZK 
analyzed the data and wrote the manuscript; all authors read, corrected and approved the manuscript.

\section{Competing financial interests}

The authors declare that they have no competing financial interest.

\section{References}

1. Bussmann RW, Paniagua-Zambrana NY, Sikharulidze S, Kikvidze Z, Kikodze D, Jinjikhadze T, Shanshiashvili T, Chelidze D, Batsatsashvili K, Bakanidze N. Wine, Beer, Snuff, Medicine and loss of diversity - Ethnobotanical travels in the Georgian Caucasus. Ethnobot Res Appl. 2014;12:237-313.

2. Nakhutsrishvili G. The vegetation of Georgia (Caucasus). Braun-Blanquetia. 1999;5:1-74.

3. Nakhutsrishvili G. The Vegetation of Georgia (South Caucasus). Stuttgart: Springer; 2012.

4. Zazanashvili N, Gagnidze R, Nakhutsrishvili G. Main types of vegetation zonation on the mountains of the Caucasus. Acta Phyt Suec. 2000;85:7-16.

5. Akhalkatsi M. Tarkhnishvili D. Habitats of Georgia, Tbilisi; 2012. p. 1-118.

6. Otte A, Akhaltkatsi M, Nakhurtsrishvili G, Simmering D. Phytodiversität in Geotgien. Die Bedeutung von Standort und Landnutzung im Grossen und Kleinen Kaukasus. Spieg Forsch. 2011;28(2):24-31.

7. Schatz G, Shulkina T, Nakhutsrishvili G, Batsatsashvili K, Tamanyan K, Alizade V, Kikodze D, Geltman D, Ekim T. Development of Plant Red List Assessments for the Caucasus Biodiversity Hotspot. In: Zazanashvili N, Mallon D, editors. Status and Protection of Globally Threatened Species in the Caucasus. Contour: USA; 2009. pp. 188-92.

8. Kimeridze M, Akhalkatsi M. Forest legislation in relation to biodiversity conservation in Georgia. In: Schmithüsen F, Herbst P, Nonic D, Jovic D, Stanisic M., editors. Legal Aspects of European Forest Sustainable Development. Forstwiss Beitr. 2006;35:176-181.

9. Javakhishvili I. Sakartvelos ekonomiuri istoria (Economic History of Georgia). Ed. 2. Vol.5. Metsniereba: Tbilisi; 1987. (In Georgian).

10. Finlayson C. Biogeography and evolution of the genus Homo. Tr Ecol Evol. 2005;20(8):457-63.

11. Gabunia L, Vekua A, Swisher CC, Ferring R, Justus A, Nioradze M, Ponce de Leon M, Tappen M, Tvalchrelidze M, Zollikofer C. Earliest Pleistocene hominid cranial remains from Dmanisi, Republic of Georgia: taxonomy, geological setting, and age. Science. 2000;288(5578):85-9.

12. Gabunia L, Vekua AA. Plio-Pleistocene hominid from Dmanisi, East Georgia. Caucasus Nature. 1995;373(6514):509-12.

13. Adler DS, Bar-Oz G. Seasonal patterns of prey acquisition during the Middle and Upper Paleolithic of the southern Caucasus. In: Hublin JJ, Richards M, editors. The evolution of hominid diets: Integrating approaches to the study of Palaeolithic subsistence. Leipzig: Springer; 2009. pp. 127-40.

14. Melikishvili G, editor. Sakartvelos istoriis narkvevebi (Historical essays of Georgia). Tbilisi; 1970. (In Georgian). 
15. Ramishvili R. Dikorastushii vinograd Zakavkazia (Wild Grape of the South Caucasus). Ganatleba: Tbilisi; 1988. (in Russian).

16. Martkoplishvili I, Kvavadze E. Some popular medicinal plants and diseases of the Upper Palaeolithic in Western Georgia. J Ethnopharmacol. 2015;166:42-52.

17. Dekaprelevich L, Menabde V. Kizucheniu polevykh kultur zapadnoi Gruzii. I. Racha. (Study of cereal cultivars in Georgia. I. Racha). Scientific Papers of the Applied Sections of the Tbilisi Botanical Garden. 1929;6(2):219-52. (In Russian).

18. Ketskhoveli N. Masalebi kulturul mtsenareta zonalobis shesastsavlad kavkasionze. (Materials on zonal distribution of cultivated plants in the Greater Caucasus). Agricultural National Committee Press: Tbilisi;; 1928. (In Georgian).

19. Ketskhoveli N. Plant cover of Georgia. Metsniereba: Tbilisi; 1960. (

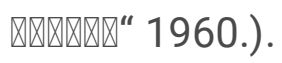

20. Ketskhoveli N. Kulturul mtsenareta zonebi sakartveloshi (Zones of cultivated plants in Georgia). Georgian Academy of Sciences Press: Tbilisi; 1957. (In Georgian).

21. Menabde V. Sakartvelos kerebi (Barleys of Georgia). Georgian Academy of Sciences Press: Tbilisi;; 1938. (In Georgian).

22. Menabde V. Pshenitsi Gruzii (Wheats of Georgia). Georgian Academy of Sciences Press: Tbilisi;; 1948. (In Russian).

23. Akhalkatsi M. Conservation and sustainable use of crop wild relatives in Samtskhe-Javakheti, Final Report GSNE Orchis: Tbilisi; 2009. p. 1-154.

24. Akhalkatsi M, Ekhvaia J, Asanidze Z. Diversity and Genetic Erosion of Ancient Crops and Wild Relatives of Agricultural Cultivars for Food: Implications for Nature Conservation in Georgia (Caucasus). In: Tiefenbacher J, editor. Perspectives on Nature Conservation - Patterns, pressures and prospects. InTech: Croatia; 2012. pp. 51-92.

25. Pistrick K, Akhalkatsi M, Girgvliani T, Shanshiashvili T. Collecting plant genetic resources in Upper Svaneti (Georgia, Caucasus Mountains). J Agr Ru Dev Trop Subtrop. 2009;Suppl 92:127-35.

26. Zhizhizlashvili K, Berishvili T. Zemo Svanetis kulturul mtsenareta shestsavlisatvis (Study of cultivated plants in Upper Svaneti). Bull Geor Acad Sci. 1980;100(2):417-9.

27. Kikvidze Z, Tevzadze G. 2014. Loss of traditional knowledge aggravates wolf-human conflict in Georgia (Caucasus) in the wake of socio-economic change. Ambio. 2014. doi:10.1007/s13280-0140580-1.

28. Ekhvaia J, Akhalkatsi M. Morphological variation and relationships of Georgian populations of Vitis vinifera L. subsp. sylvestris (C.C. Gmel.) Hegi. Flora. 2010;205:608-617.

29. Ketskhoveli N, Ramishvili M, Tabidze D. Sakartvelos ampelograpia. (Amphelography of Georgia). Georgian Academy of Sciences Press: Tbilisi; 1960. (In Georgian).

30. This P, Lacombe T, Thomas MR. Historical origins and genetic diversity of wine grapes. $\operatorname{Tr}$ Genet. 2006;22(9):511-9. 
31. Bedoshvili D. National report on the state of plant genetic resources for food and agriculture in Georgia. Ministry of Agriculture: Tbilisi; 2008. http://www.pgrfa.org/gpa/geo/Georgian report on State of PGR Sep 29, 2008.pdf.

32. Badr A, Müller K, Schäfer-Pregl R, El Rabey H, Effgen S, Ibrahim HH, Pozzi C, Rohde W, Salamini F. On the origin and domestication history of barley (Hordeum vulgare). Mol Biol Evol. 2000;17(4):499510 .

33. Akhalkatsi M, Girgvliani T. Landraces and wild species of the Secale genus in Georgia (Caucasus ecoregion). Agr Res Tech. 2016;1(4).

34. Castañeda-Álvarez NP, Khoury CK, Achicanoy HA, Bernau V, Dempewolf H, Eastwood RJ, Guarino L, Harker RH, Jarvis A, Maxted N, Müller JV, Ramirez-Villegas J, Sosa CC, Struik PC, Vincent H, Toll J. Global conservation priorities for crop wild relatives. Nature Plants. 2016. doi:10.1038/NPLANTS.2016.22.

35. Kan M, Küçükçongar M, Keser M, Morgounov A, Muminkanv A, Özdemir F, Qualset C. Wheat landraces in farmer's fields in Turekey. Food and Agricultiural Organization of the United Nations: Ankara; 2015.

36. Asanidze Z, Akhalkatsi M, Gvritishvili M. Comparative morphometric study and relationships between the Caucasian species of wild pear (Pyrus spp.) and local cultivars in Georgia. Flora. 2011;206:97486.

37. Akhalkatsi M, Kimeridze M, Maisaia I, Mosulishvili M. Flawless Profits. Cauc Env. 2005;4(13):34-7.

38. Pieroni A, Sõukand R, Bussmann RW. The inextricable link between food and linguistic diversity: Wild food plants among diverse minorities in NE Georgia, Caucasus. Econ Bot. 2020;74:379-97.

39. Batsatsashvili K, Kikvidze Z, Bussmann RW, editors. Ethnobotany of Mountain Regions - Far Eastern Europe. Cham: Springer International Publishing; 2020a.

40. Batsatsashvili K, Kikvidze Z, Bussmann RW, editors. Ethnobotany of Mountain Regions - Central Asia and Altai. Cham: Springer International Publishing; 2020b.

41. Bussmann RW, editor. Ethnobotany of the Caucasus. Cham: Springer International Publishing; 2017.

42. Bussmann RW, Paniagua Zambrana NY, Sikharulidze S, Kikvidze Z, Darchidze M, Manvelidze Z, Ekhvaia J, Kikodze D, Tchelidze D, Khutsishvili M, Batsatsashvili K, Hart RE. Form the sea to the mountains - plant use in Ajara, Samegrelo and Kvemo Svaneti, Sakartvelo (Republic of Georgia), Caucasus. Ethnobot Res Appl 2020c;20(9) https://doi.org/10.32859/era.20.9.1-34.

43. Bussmann RW, Paniagua Zambrana NY, Sikharulidze S, Kikvidze Z, Kikodze D, Tchelidze D, Khutsishvili M, Batsatsashvili K, Hart RE. An ethbobotany iof Kahkheti and Kvemo Kartli, Sakartvelo (Republic of Georgia), Caucasus. Ethnobot Res Appl 2020d;19(35) https://doi.org/10.32859/era.19.47.1-28.

44. Bussmann RW, Paniagua Zambrana NY, Sikharulidze S, Kikvidze Z, Kikodze., Tchelidze D, Batsatsashvili K, Hart RE. Unequal brothers - Plant and fungal use in Guria and Racha, Sakartvelo (Republic of Georgia), Caucasus. Ind J Trad Know. 2018;17(1):7-33. 
45. Bussmann RW, Paniagua Zambrana NY, Sikharulidze S, Kikvidze Z, Kikodze., Tchelidze D, Batsatsashvili K, Hart RE. (2017). Plant and fungal use in Tusheti, Khevsureti and Pshavi, Sakartvelo (Republic of Georgia), Caucasus. Act Soc Bot Pol 2017a;86(2):3517. https://doi.org/10.5586/asbp.3517.

46. Bussmann RW, Paniagua Zambrana NY, Sikharulidze S, Kikvidze Z, Kikodze D, Tchelidze D, Batsatsashvili K, Hart RE. Plants in the spa - the medicinal plant market of Borjomi, Sakartvelo (Republic of Georgia), Caucasus. Ind J Trad Know. 2017b;16(1):25-34.

47. Bussmann RW, Paniagua Zambrana NY, Sikharulidze S, Kikvidze Z, Kikodze., Tchelidze D, Batsatsashvili K, Hart RE. Ethnobotany of Samtskhe-Javakheti, Sakartvelo (Republic of Georgia), Caucasus. Ind J Trad Know. 2017c;16(1):7-24.

48. Bussmann RW, Paniagua Zambrana NY, Sikharulidze S, Kikvidze Z, Kikodze, Tchelidze D, Batsatsashvili K, Hart RE, Pieroni A. Your poison in my pie - the use of Potato (Solanum tuberosum L.) leaves in Sakartvelo, Georgia (Caucasus) and Gollobordo, Eastern Albania. Econ Bot. 2016a;70(4):431-7.

49. Bussmann RW, Paniagua Zambrana NY, Sikharulidze S, Kikvidze Z, Kikodze, Tchelidze D, Batsatsashvili K, Hart RE. A comparative ethnobotany of Khevsureti, Samtskhe-Javakheti, Tusheti, Svaneti, and Racha-Lechkhumi, Republic of Georgia (Sakartvelo), Caucasus. J Ethnobiol Ethnomed 201bc;12:43, https://doi.org/10.1186/s13002-016-0110-2.

50. Bussmann RW, Paniagua Zambrana NY, Sikharulidze S, Kikvidze Z, Kikodze., Tchelidze D, Batsatsashvili K, Hart RE. (2016). Medicinal and food plants of Svaneti and Lechkhumi, Sakartvelo (Republic of Georgia), Caucasus. Med Arom PI 2016c;5:266. https://doi.org/10.4172/21670412.1000266 .

51. Kazancı C, Oruç S, Mosulishvili M. Medicinal ethnobotany of wild plants: a cross-cultural comparison around Georgia- Turkey border, the Western Lesser Caucasus. J Ethnobiol Ethnomed. 2020;16:71. https://doi.org/10.1186/s13002-020-00415-y.

52. Łuczaj $Ł$, Tvalodze B, Zalkaliani D. Comfrey and Buttercup Eaters: Wild Vegetables of the Imereti Region in Western Georgia, Caucasus. Econ Bot. 2017;71:188-93.

53. Eyzaguirre PB, Linares OF., editors. Home Gardens and Agrobiodiversity. Smithsonian Books: Washington DC; 2004.

54. Alcorn JB. 1992. Indigenous agroforestry systems in the Latin American tropics. In: Altieri MA, Hecht SB., editors. Agroecology and small farm development. CRC Press: Boston; 1992. p. 203-218.

55. Merrick LC. Crop genetic diversity and its conservation in traditional agroecosystems. In: Altieri MA, Hecht SB, editors. Agroecology and small farm development. Boston: CRC Press; 1992. pp. 3-11.

56. Poot Pool WS, van de Wal H, Flores-Guido S, Pat-Fernández JM, Esparza-Olguín L. Homegarden agrobiodiversity differentiates along a rural-peri-urban gradient in Campeche, México. Econ Bot. 2015;69(3):203-17.

57. Smith NJH. Home gardens as a springboard for agroforestry development in Amazonia. Tree Crops J. 1996;9:11-30. 
58. Coomes OT, Ban N. Cultivated plant species diversity in home gardens of an Amazonian peasant village in northeastern Peru. Econ Bot. 2004;58:420-34.

59. Colunga-García MP, Zizumbo-Villarreal D. Domestication of plants in Maya lowlands. Econ Bot. 2004;58(Supplement):101-10.

60. Das T, Kumar Das A. Conservation of Plant Diversity in Rural Homegardens with Cultural and Geographical, Variation in Three Districts of Barak Valley, Northeast India. Econ Bot. 2015;69(1):5771.

61. Reyes-García V, Aceituno L, Vila S, Calvet-Mir L, Garnatje T, Jesch A, Lastra JJ, Parada M, Rigat M, Vallès J, Pardo-de-Santayana M. Home gardens in three mountain regions of the lberian peninsula: Description, motivation for gardening, and gross financial benefits. J Sust Agr. 2012;36(2):249-70.

62. Reyes-García V, Guèze M, Luz AC, Paneque-Gálvez J, Macía MJ, Orta-Martínez M, Pinod J, RubioCampilloe $X$. Evidence of traditional knowledge loss among a contemporary indigenous society. Evol Hum Behav. 2013;34(4):249-257.

63. Reyes-García V, Vila S, Aceituno-Mata L, Calvet-Mir L, Garnatje T, Jesch A, Lastra JJ, Parada M, Rigat M, Valles J, Pardo-de-Santayana M. Gendered home gardens: A study in three mountain areas of the Iberian península. Econ Bot. 2010;64(3):235-47.

64. Vogl-Lukasser B, Vogl CR, Gütler M, Heckler S. Plant species with spontaneous reproduction in home gardens in Eastern Tyrol (Austria): Perception and management by women farmers. Ethnobot Res Appl. 2010;8:1-15.

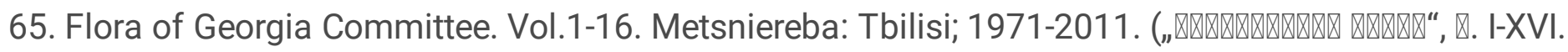
1971-2011).

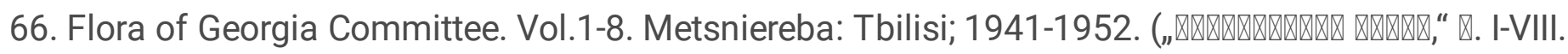
1941-1952).

67. Gagnidze R. Vascular Plants of Georgia. A Nomenclatural Checklist. Metsniereba: Tbilisi; 2005. (『.

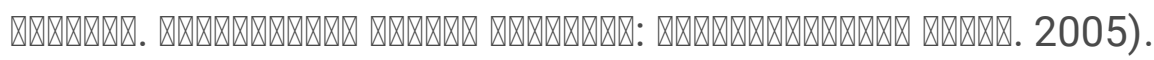

68. Makashvili A. 1991. Botanical Dictionary. Plant Names. 3rd ed. Tbilisi.

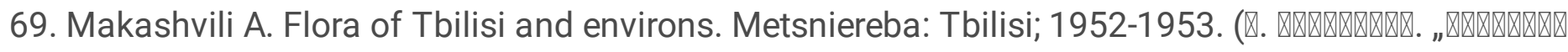

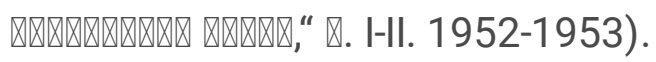

70. Angiosperm Phylogeny Group. An update of the Angiosperm Phylogeny Group classification for the orders and families of flowering plants: APG III. Bot J Linn Soc. 2009;161(1):105-21.

71. Hammer $\varnothing$, Harper DAT, Ryan PD. PAST: Paleontological statistics software package for education and data analysis. Palaeontologia Electronica. 2001;4(1):9. http://palaeoelectronica.org/2001_1/past/issue1_01.htm.

72. Hervé M. 2020. RVAideMemoire: Testing and Plotting Procedures for Biostatistics.

73. Alarcón R, Pardo-de-Santayana M, Priestley C, Morales R, Heinrich M. Medicinal and local food plants in the south of Alava (Basque Country, Spain). J Ethnopharmacol. 2015;176:207-24. 
74. Cakilcioğlu U, Khatun S, Turkoğlu I, Hayta S. Ethnopharmacological survey of medicinal plants in Maden (Elaziğ-Turkey). J Ethnopharmacol. 2011;137:469-86.

75. Cakilcioğlu U, Turkoğlu I. An ethnobotanical survey of medicinal plants in Sivrice (Elazığ Turkey). J Ethnopharmacol. 2010;132:165-75.

76. Dogan Y, Nedelcheva A, Łuczaj Ł, Drăgulescu C, Stefkov G, Maglajlić A, Ferrier J, Papp N, Hajdari A, Mustafa B, Dajić-Stevanović Z, Pieroni A. Of the importance of a leaf: the ethnobotany of sarma in Turkey and the Balkans. J Ethnobiol Ethnomed. 2015;11:26. doi:10.1186/s13002-015-0002-x.

77. Dogan $Y$, Nedelcheva A. Wild plants from open markets on both sides of the Bulgarian-Turkish border. Ind J Trad Know. 2015;14(3):351-8.

78. Ferrier J, Saciragic L, Trakić S, Chen ECH, Gendron RL, Cuerrier A, Balick MJ, Redžić S, Alikadić E, Arnason JT. An ethnobotany of the Lukomir Highlanders of Bosnia \& Herzegovina. J Ethnobiol Ethnomed. 2015;11:81. doi 10.1186/s13002-015-0068-5.

79. Guarrera A, Savo V. Wild food plants used in traditional vegetable mixtures in Italy. $J$ Ethnopharmacol. 2015;185:202-34.

80. Licata M, Tuttolomondo T, Leto C, Virga G, Bonsangue G, Cammalleri I, Gennaro MC, La Bella S. A survey of wild plant species for food use in Sicily (Italy) - results of a 3-year study in four Regional Parks. J Ethnobiol Ethnomed. 2016;12:12. doi 10.1186/s13002-015-0074-7.

81. Łuczaj $Ł$, Dolina K. A hundred years of change in wild vegetable use in southern Herzegovina. J Ethnopharmacol. 2015;166:297-304.

82. Łuczaj $Ł$, Stawarczyk K, Kosiek T, Pietras M, Kujawa A. 2015. Wild food plants and fungi used by Ukrainians in the western part of the Maramureş region in Romania. Act Soc Bot Pol. 2015;84(3):339-346. doi:10.5586/asbp.2015.029.

83. Łuczaj Ł, Pieroni A, Tardío J, Pardo-de-Santayana M, Sõukand R, Svanberg I, Kalle R. Wild food plant use in 21 st century Europe: the disappearance of old traditions and the search for new cuisines involving wild edibles. Act Soc Bot Pol. 2012. doi:10.5586/asbp.2012.031.

84. Łuczaj $t$, Szymański WM. Wild vascular plants gathered for consumption in the Polish countryside: a review. J Ethnobiol Ethnomed. 2007;3:17. doi:10.1186/1746-4269-3-17.

85. Menendez-Baceta G, Aceituno-Mata L, Molina M, Reyes-García V, Tardío J, Pardo-de-Santayana M. Medicinal plants traditionally used in the northwest of the Basque Country (Biscay and Alava), Iberian Peninsula. J Ethnopharmacol. 2014;152:113-34.

86. Menendez-Baceta G, Aceituno-Mata L, Tardío J, Reyes-García V, Pardo-de-Santayana M. Wild edible plants traditionally gathered in Gorbeialdea (Biscay, Basque Country). Genet Res Crop Evol. 2012;59:1329-47.

87. Molina M, Tardío J, Aceituno-Mata L, Morales R, Reyes-García V, Pardo-de-Santayana M. Weeds and food diversity: natural yield assessment and future alternatives for traditionally consumed wild vegetables. J Ethnopharmacol. 2014;34(1):44-67.86.

88. Mükemre M, Behçet L, Çakılcıoğlu U. Ethnobotanical study on medicinal plants in villages of Çatak (Van-Turkey). J Ethnopharmacol. 2015;166:361-74. 
89. Pardo-de-Santayana M, Morales R, Aceituno-Mata L, Molina M, editors. Inventario español de los conocimientos tradicionales relativos a la biodiversidad. Alimentación y Medio Ambiente: Madrid;: Ministerio de Agricultura; 2014. pp. 1-411.

90. Pieroni A, Ibraliu A, Abbasi AM, Papajani-Toska V. An ethnobotanical study among Albanians and Aromanians living in the Rraicë and Mokra areas of Eastern Albania. Gen Res Crop Evol. 2014. 10.1007/s10722-014-0174-6.. . doi.

91. Pieroni A, Nedelcheva A, Dogan Y. Local knowledge of medicinal plants and wild food plants among Tatars and Romanians in Dobruja (South-East Romania). Gen Res Crop Evol. 2015;62:605-20. doi:10.1007/s10722-014-0185-3.

92. Sõukand R, Pieroni A. The importance of a border: Medical, veterinary, and wild food ethnobotany of the Hutsuls living on the Romanian and Ukrainian sides of Bukovina. J Ethnopharmacol. 2016;185:17-40.

93. Stryamets N, Elbakidze M, Ceuterick M, Angelstam P, Axelsson R. From economic survival to recreation: contemporary uses of wild food and medicine in rural Sweden. Ukraine NW Russia J Ethnobiol Ethnomed. 2015;11:53. doi:10.1186/s13002-015-0036-0.

94. Manduzai AK, Abbasi AM, Khan SM, Abdullah A, Prakofjewa J, Amini MH, Amjad MS, Cianfaglione K, Fontefrancesco MF, Soukand R, Pieroni A. The Importance of Keeping Alive Sustainable Foraging Practices: Wild Vegetables and Herbs Gathered by Afghan Refugees Living in Mansehra District. Pakistan Sustainabil. 2021;13:1500. https://doi.org/10.3390/su13031500.

95. Mattalia G, Sõukand R, Corvo P, Pieroni A. "We Became Rich and We Lost Everything”: Ethnobotany of Remote Mountain Villages of Abruzzo and Molise, Central Italy Hum Ecol 2021; https://doi.org/10.1007/s10745-020-00209-6.

96. Mattalia G, Sõukand R, Corvo P, Pieroni A. Dissymmetry at the Border: Wild Food and Medicinal Ethnobotany of Slovenes and Friulians in NE Italy. Econ Bot. 2020;74(1):1-14.

97. Mattalia G, Sõukand R, Corvo P, Pieroni A. Wild Food Thistle Gathering and Pastoralism: An Inextricable Link in the Biocultural Landscape of Barbagia, Central Sardinia (Italy. Sustainab. 2020;12:5105. https://doi.org/10.3390/su12125105.

98. Mattalia G, Stryamets N, Pieroni A, Sõukand R. Knowledge transmission patterns at the border: ethnobotany of Hutsuls living in the Carpathian Mountains of Bukovina (SW Ukraine and NE Romania. J Ethnobiol Ethnomed. 2020;16:41. https://doi.org/10.1186/s13002-020-00391-3.

99. Mustafa B, Hajdari A, Pulaj B, Quave CL, Pieroni A. Medical and food ethnobotany among Albanians and Serbs living in the Shtërpcë/Štrpce area, South Kosovo J Herb Med 2020;22.

100. Nedelcheva A, Pieroni A, Dogan Y. Folk food and medicinal botanical knowledge among the last remaining Yörüks of the Balkans. Act Soc Bot Pol. 2017;86(2):3522. https://doi. org/10.5586/asbp.3522.

101. Pawera L, Łuczaj $Ł$, Pieroni A, Polesny Z. Traditional Plant Knowledge in the White Carpathians: Ethnobotany of Wild Food Plants and Crop Wild Relatives in the Czech Republic. Hum Ecol. 2017;45(1):1-17. https://doi.org/10.1007/s10745-017-9938-x. 
102. Pieroni A, Sõukand R, Quave CL, Hajdari A, Mustafa B. Traditional food uses of wild plants among the Gorani of South Kosovo. Appet. 2018;108:83e92.

103. Pieroni A, Sõukand R. Are borders more important than geographical distance? The wild food ethnobotany of the Boykos and its overlap with that of the Bukovian Hutsuls in Western Ukraine. $J$ Ethnobiol 2017; 37(2):326-345 2017.

104. Pieroni A. Traditional uses of wild food plants, medicinal plants, and domestic remedies in Albanian, Aromanian and Macedonian villages in South-Eastern Albania. J Herb Med. 2017;9:81-90.

105. Pieroni P, Renta Sõukand S. The disappearing wild food and medicinal plant knowledge in a few mountain villages of North-Eastern Albania. J Appl. Bot Food Qual 2017;90:58-67 (2017), https://doi.org/10.5073/JABFQ.2017.090.009.

106. Rigat M, Gras A, D’Ambrosio U, Garnatje T, Parada M, Vallès J. Wild food plants and minor crops in the Ripollès district (Catalonia, Iberian Peninsula): potentialities for developing a local production, consumption and exchange program Rigat et al. J Ethnobiol Ethnomed. 2016;12:49. https://doi.org/10.1186/s13002-016-0122-y.

107. Sõukand R, Hrynevich Y, Vasilyeva I, Prakofjewa J, Vnukovich Y, Paciupa J, Hlushko A, Knureva Y, Litvinava Y, Vyskvarka S, Silivonchyk H, Paulava A, Kõiva M, Kalle R. Multi-functionality of the few: current and past uses of wild plants for food and healing in Liubań region, Belarus. J Ethnobiol Ethnomed. 2017;13:10. https://doi.org/10.1186/s13002-017-0139-x.

108. Stryamets N, Mattalia G, Pieroni A, Khomyn I, Sõukand R. Dining Tables Divided by a Border: The Effect of Socio-Political Scenarios on Local Ecological Knowledge of Romanians Living in Ukrainian and Romanian Bukovina. Foods. 2021;10:126. https://doi.org/10.3390/foods10010126.

109. Pieroni A, Sõukand R, Amin HIM, Zahir H, Kukk T. Celebrating Multi-Religious Co-Existence in Central Kurdistan: the Bio-Culturally Diverse Traditional Gathering of Wild Vegetables among Yazidis, Assyrians, and Muslim Kurds. Hum Ecol. 2018;46:217-27. https://doi.org/10.1007/s10745-0189978-x.

110. Pieroni P, Zahir H, Amin HIM, Sõukand R. Where tulips and crocuses are popular food snacks: Kurdish traditional foraging reveals traces of mobile pastoralism in Southern Iraqi Kurdistan Pieroni et al. J Ethnobiol Ethnomed. 2019;15:59. https://doi.org/10.1186/s13002-019-0341-0.

111. Yeşil Y, Çelik M, Yılmaz B. Wild edible plants in Yeşilli (Mardin-Turkey), a multicultural area. J Ethnobiol Ethnomed. 2019;15:52. https://doi.org/10.1186/s13002-019-0327-y.

112. Kaliszewska I, Kołodziejska-Degórska I. 2015. The social context of wild leafy vegetables uses in Shiri, Daghestan. J Ethnobiol Ethnomed. 2015;11:63. doi:10.1186/s13002-015-0047-x.

113. Sõukand S, Pieroni A. Resilience in the mountains: biocultural refugia of wild food in the Greater Caucasus Range, Azerbaijan. Biodiv Cons. 2019;28:3529-45. https://doi.org/10.1007/s10531-01901835-3.

114. Pieroni A, Sõukand R. Ethnic and religious affiliations affect traditional wild plant foraging in Central Azerbaijan. Genet Res Crop Evol. 2019;66:1495-513. https://doi.org/10.1007/s10722-019-008029(0123456789.,-volV 0123458697.,-volV). 
115. Pieroni A, Hovsepyan R, Manduzai AK, Sõukand R. Wild food plants traditionally gathered in central Armenia: archaic ingredients or future sustainable foods? Env Dev Sust. 2021;23:2358-81. https://doi.org/10.1007/s10668-020-00678-1.

116. Nanagulyan S, Zakaryan N, Kartashyan N, Piwowarczyk R, Łuczaj $Ł$. Wild plants and fungi sold in the markets of Yerevan (Armenia) Nanagulyan et al. J Ethnobiol Ethnomed. 2020;16:26. https://doi.org/10.1186/s13002-020-00375-3.

117. Akhalkatsi M, Mosulishvili M, Kimeridze M, Maisaia I. Conservation and sustainable utilization of rare medicinal plants in Samtskhe-Javakheti. Tbilisi; 2008. pp. 1-200.

118. Akhalkatsi M, Fritsch RM, Maisaiac I, Nakhutsrishvilia G, Pistrick K. Habitats of Allium species in Georgia. Keusgen M, Fritsch RM., editors. Proceedings of the first Kazbegi workshop on „Botany, taxonomy and phytochemis.try of wild Allium L. species of the Caucasus and Central Asia," June 48; 2007. p. 45-52.

119. Nakhutsrishvili G, Akhalkatsi M, Abdaladze O. Main Threats to Mountain Biodiversity in Georgia. Mt For Bull. 2009;9(2):15-8.

120. Akhalkatsi M, Ekhvaia J, Mosulishvili M, Nakhutsrishvili G, Abdaladze O, Batsatsashvili K. Reasons and processes leading to the erosion of crop genetic diversity in mountainous regions of Georgia. Mt Res Dev. 2010;30(3):304-10.

121. Schunko C, Grasser S, Vogl CR. 2015. Explaining the resurgent popularity of the wild: motivations for wild plant gathering in the Biosphere Reserve Grosses Walsertal, Austria, J Ethnobiol Ethnomed. 2015;11:55. doi:10.1186/s13002-015-0032-4.

\section{Tables}

Due to technical limitations, table 1-3 is only available as a download in the Supplemental Files section.

\section{Figures}




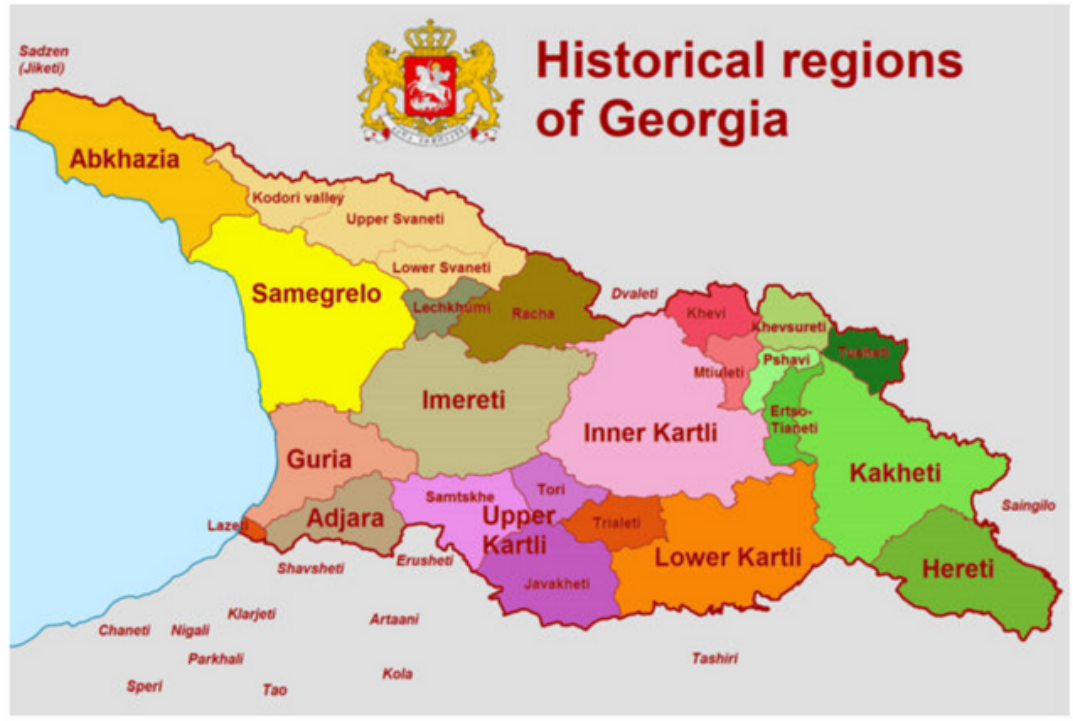

Figure 1. Location and Historical provinces of Georgia

\section{Figure 1}

See image above for figure legend. 


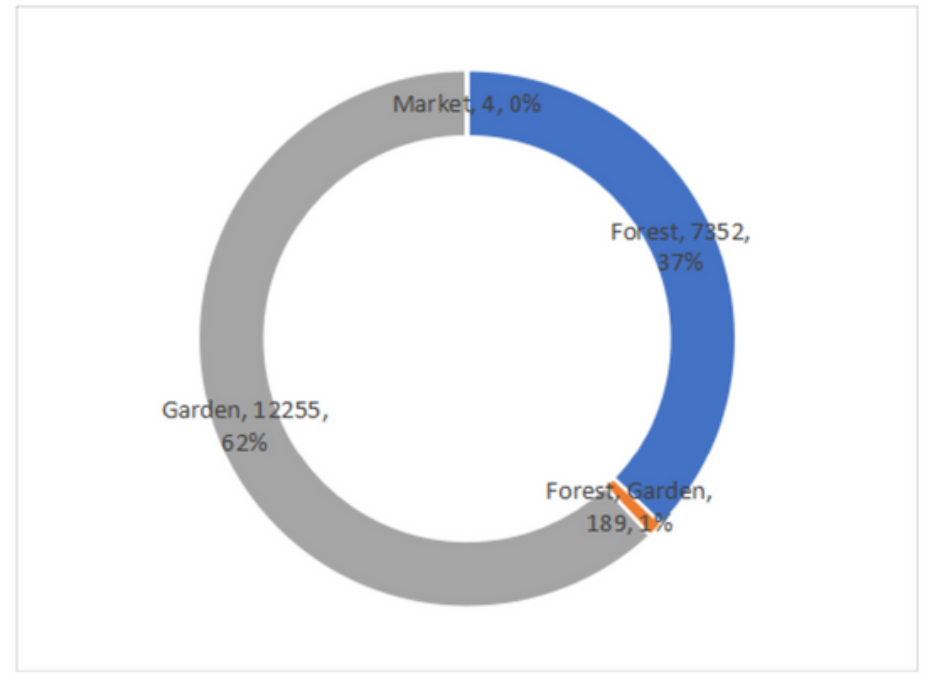

Figure 2. Plant family distribution in food plant groups, based on use reports.

Figure 2

See image above for figure legend. 


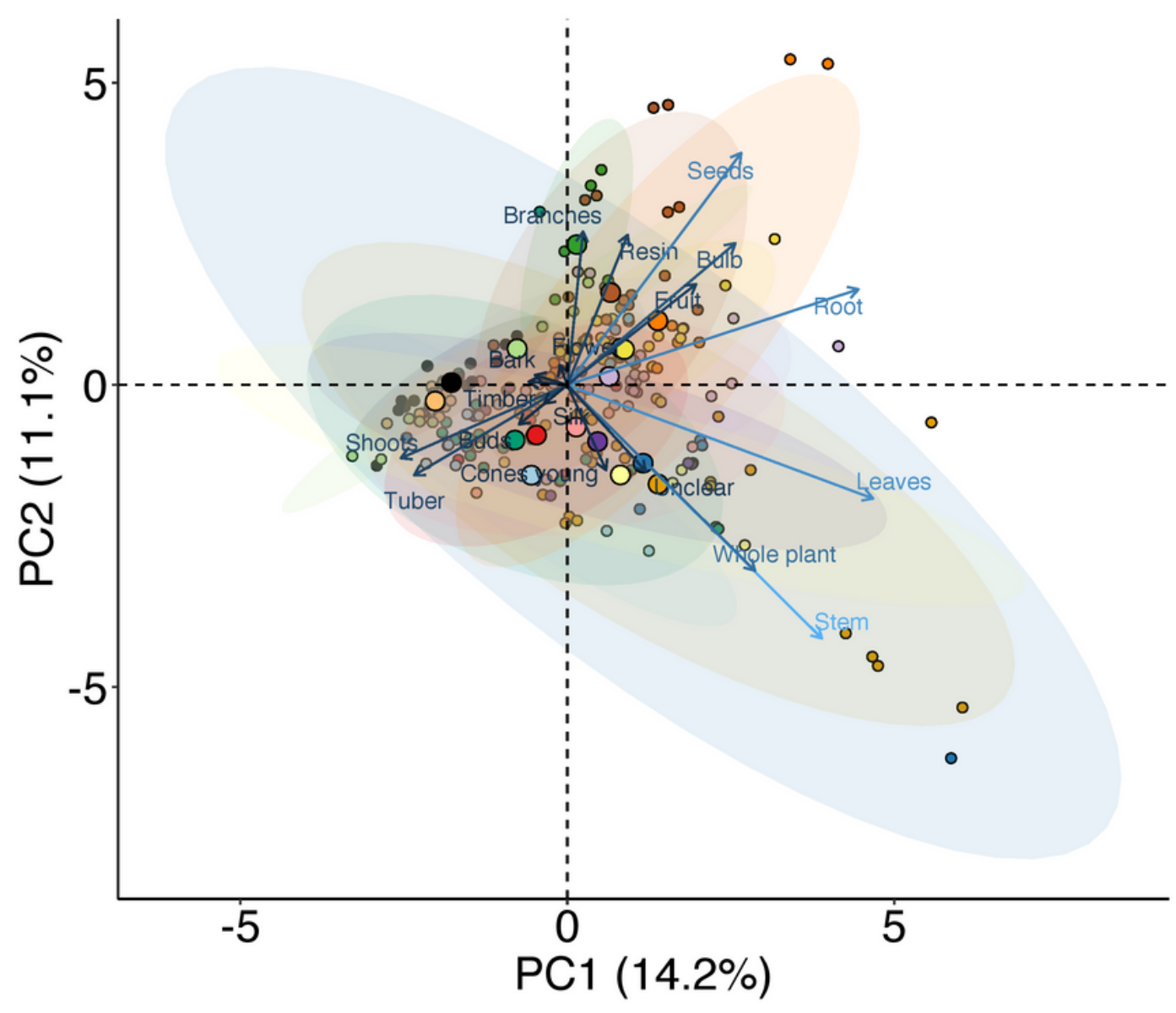

- Adjara

- Guria

- Javakheti Plateau

- Kakheti

- Khevsureti

- Kvemo Kartli

- Kvemo Racha

- Kvemo Svaneti

- Lechkhumi

o Meskheti

- Mtianeti

- Samegrelo

- Tori

- Tusheti

- Zemo Imereti

- Zemo Racha

- Zemo Svaneti

Contribution

15

10

5

Figure 3

Principal Component Analysis comparing the usage of plants based on their specific parts (bark, branches, buds, bulb, cones, flowers, fruit, latex, leaves, resin, roots, seeds, shoots, silk, stem, timber, tuber, whole plant) used. Contribution represents how each family contributes to the overall dissimilarity between regions based on their distance on the ordination. Arrows represent the specific plant parts used, small dots the samples and larger dots the centroid of each region. 


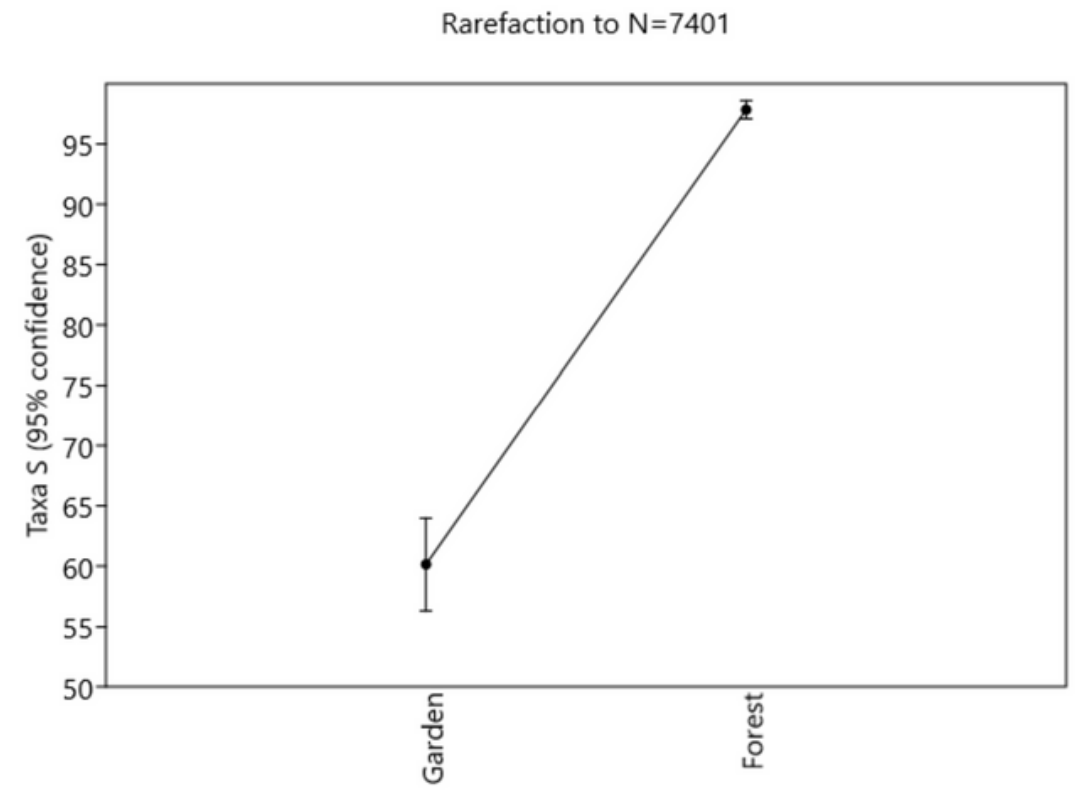

Figure 4. Rarefaction comparison of minimum size samples: wild plant families were significantly more numerous than the garden ones.

\section{Figure 4}

See image above for figure legend. 


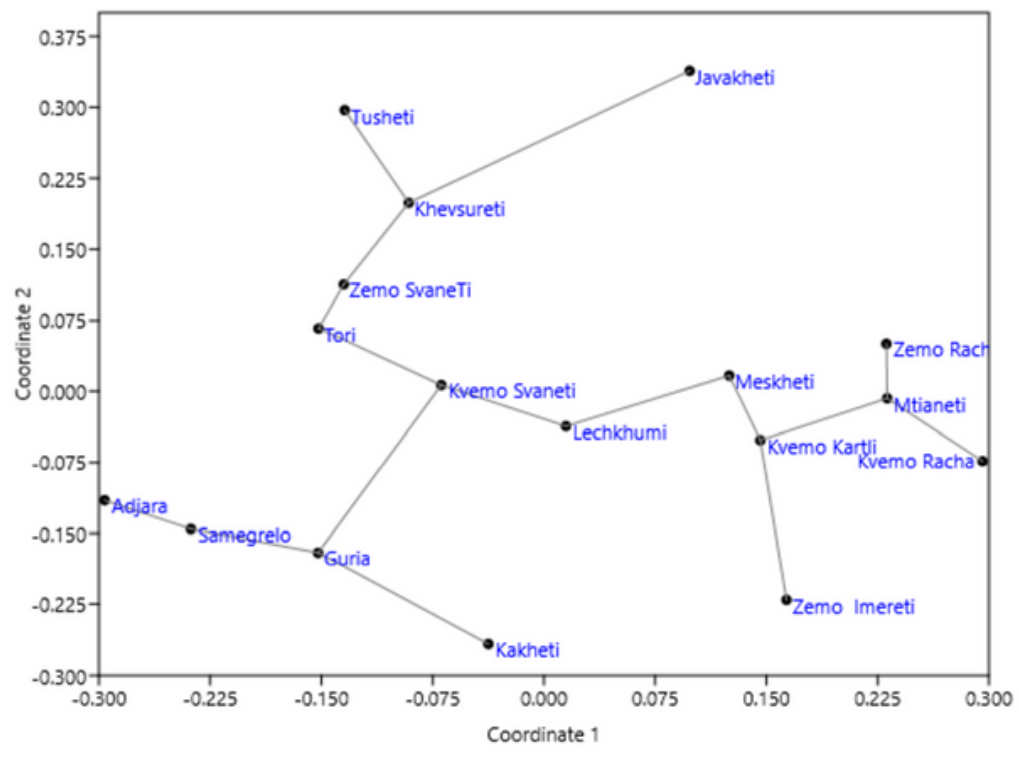

Figure 5. nMDS ordination of regions by garden food plant species composition.

Figure 5

See image above for figure legend. 


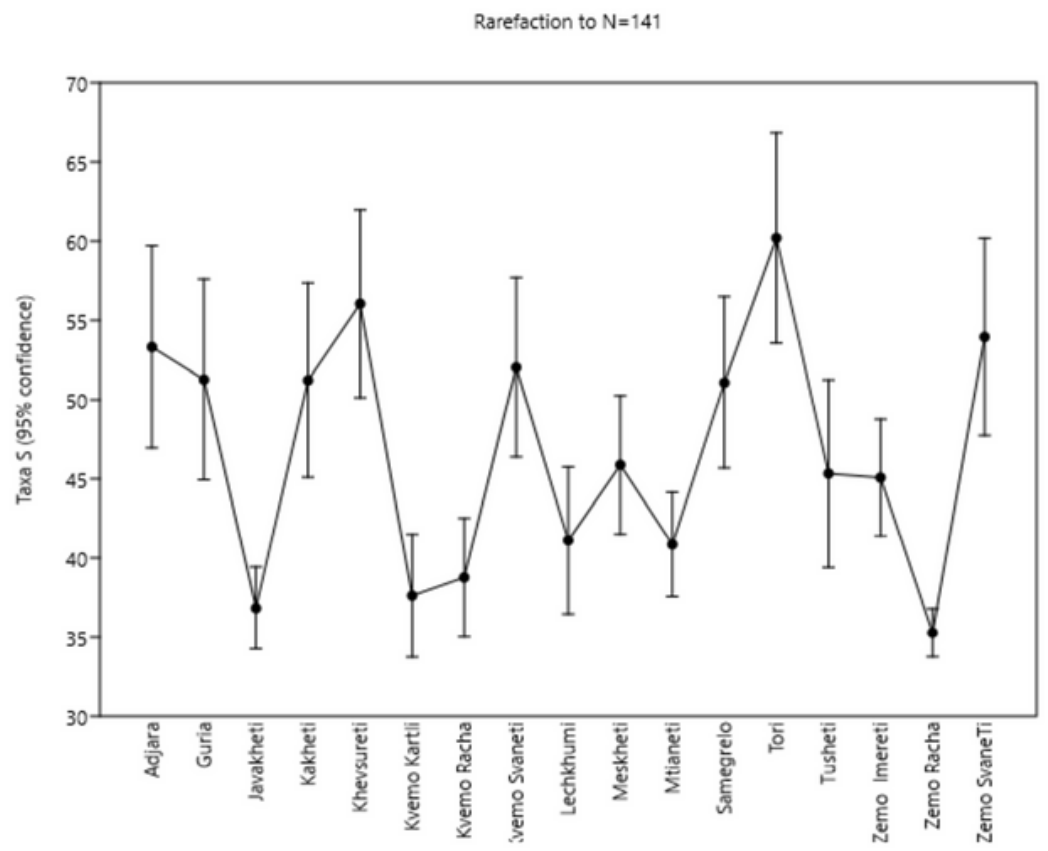

Figure 6. Rarefaction of species richness of the garden food plants across the regions.

Figure 6

See image above for figure legend. 


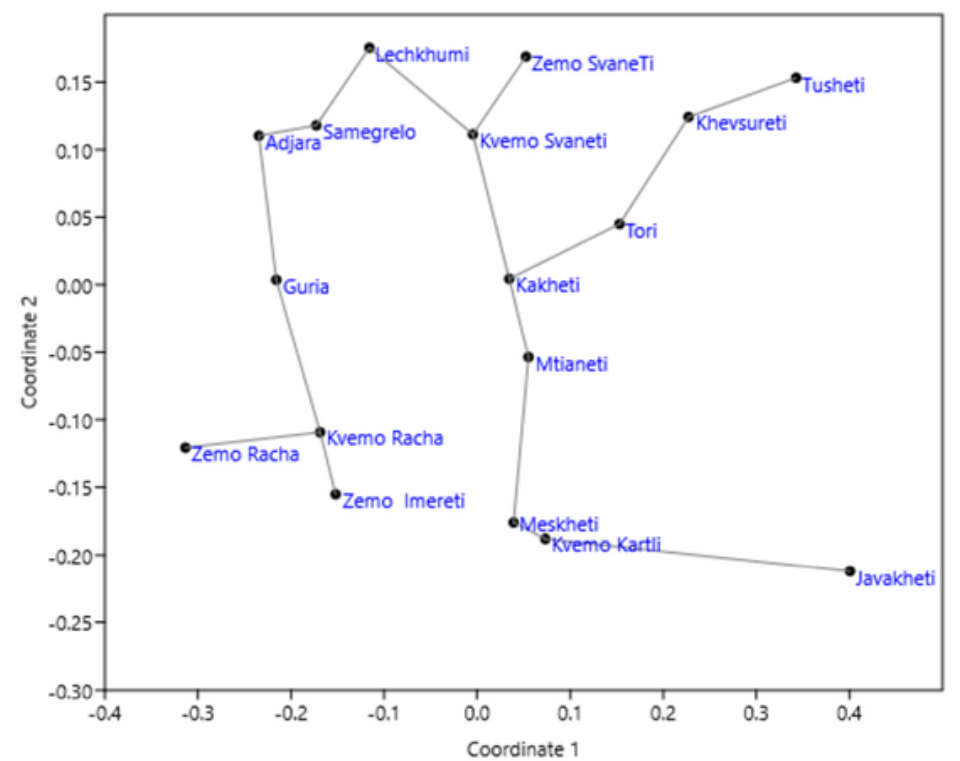

Figure 7. nMDS ordination of regions by wild food plant species composition.

\section{Figure 7}

See image above for figure legend. 


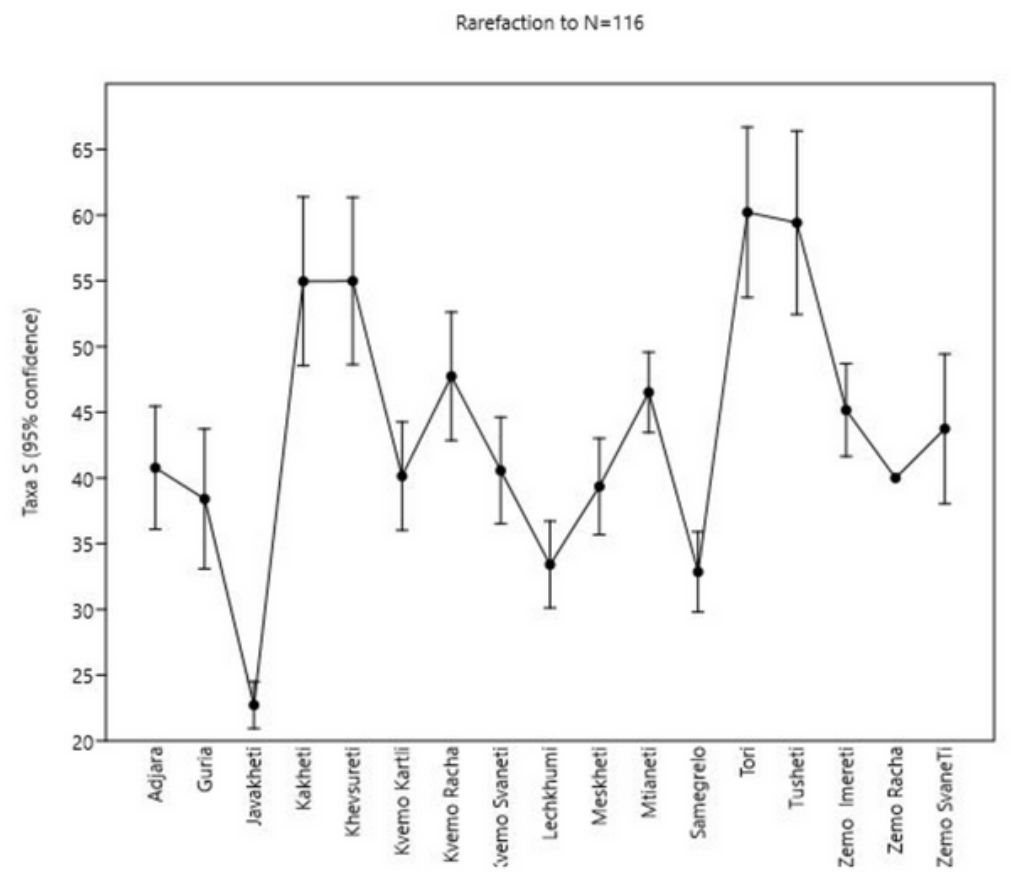

Figure 8. Rarefaction of species richness of the wild food plants across the regions.

Figure 8

See image above for figure legend. 
a) Family

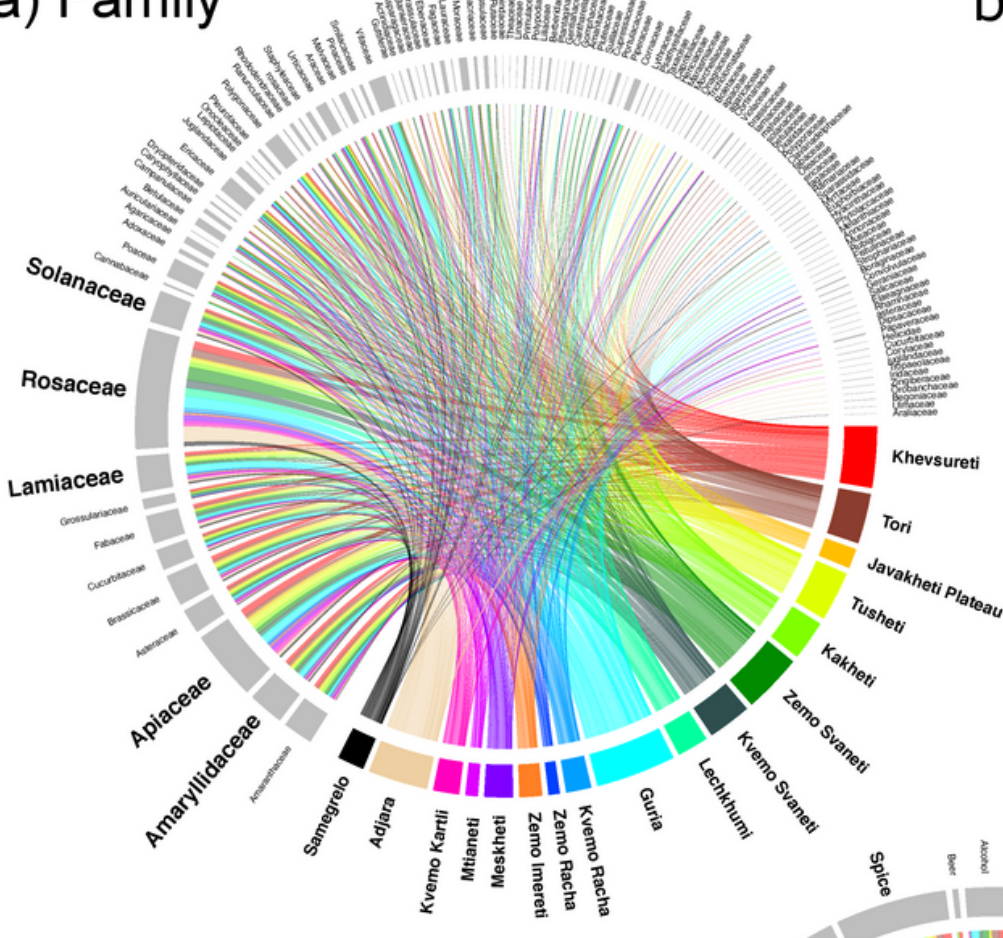

b) Genus

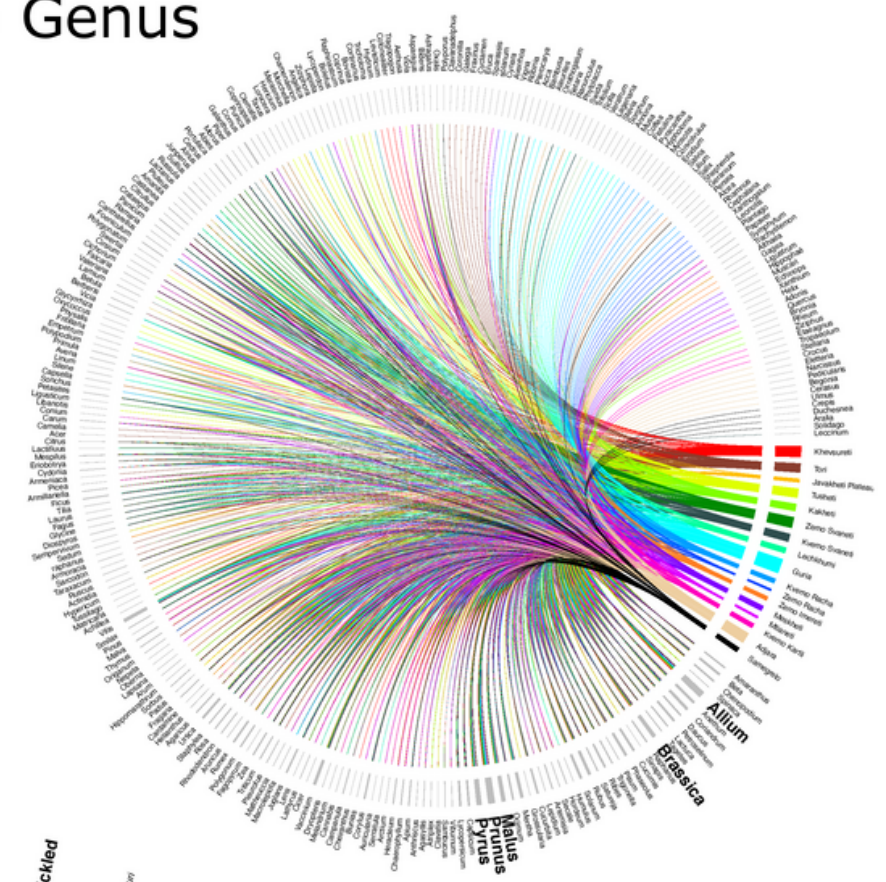

c) Usage
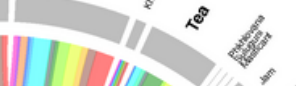

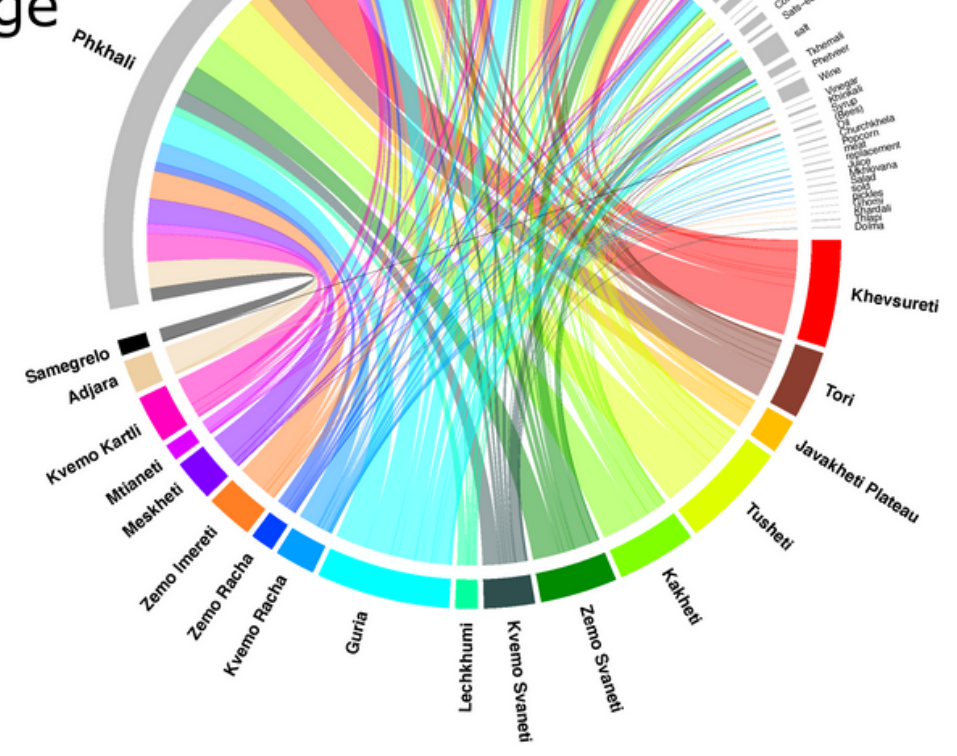

Figure 9

Relationship between families, genera and usage within regions. 
a) Family

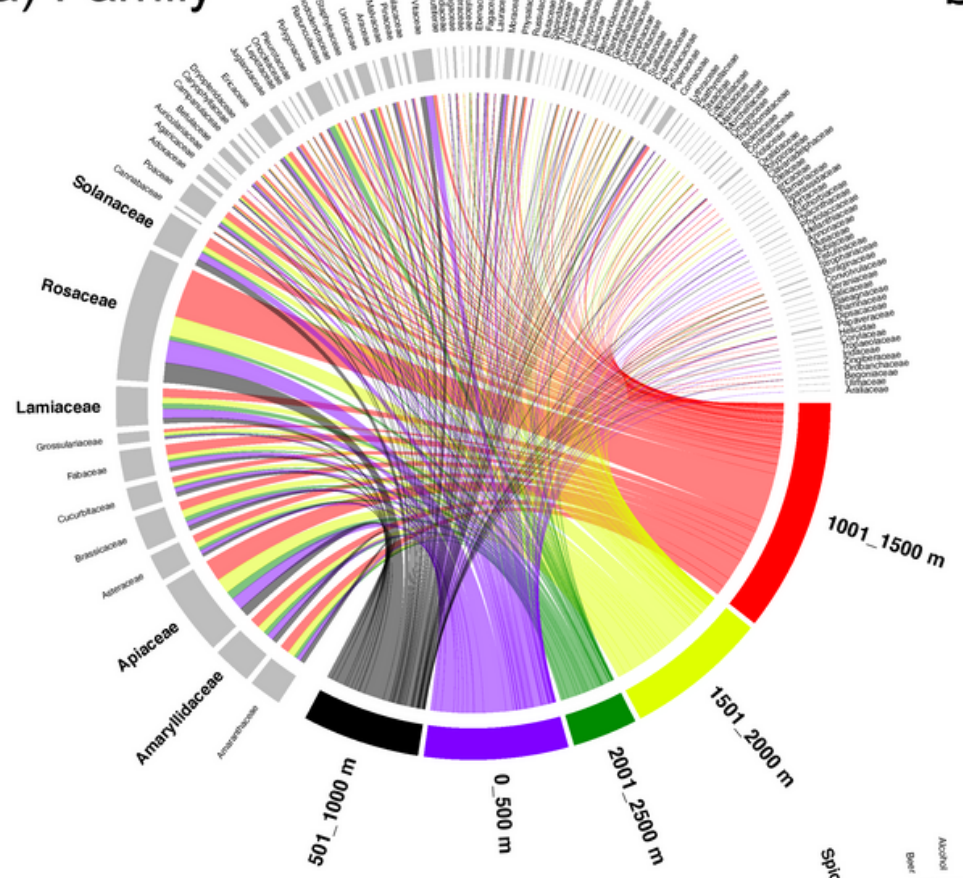

b) Genus

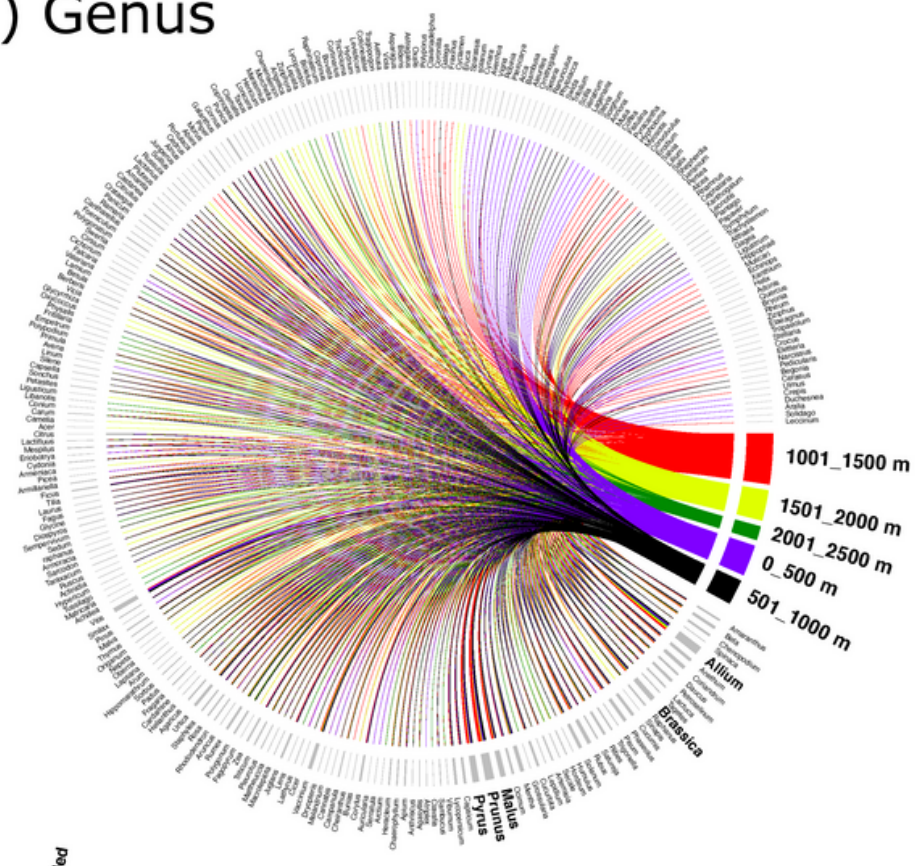

c) Usage

Figure 10

Relationship between families, genera and usage within the altitudinal gradients. 


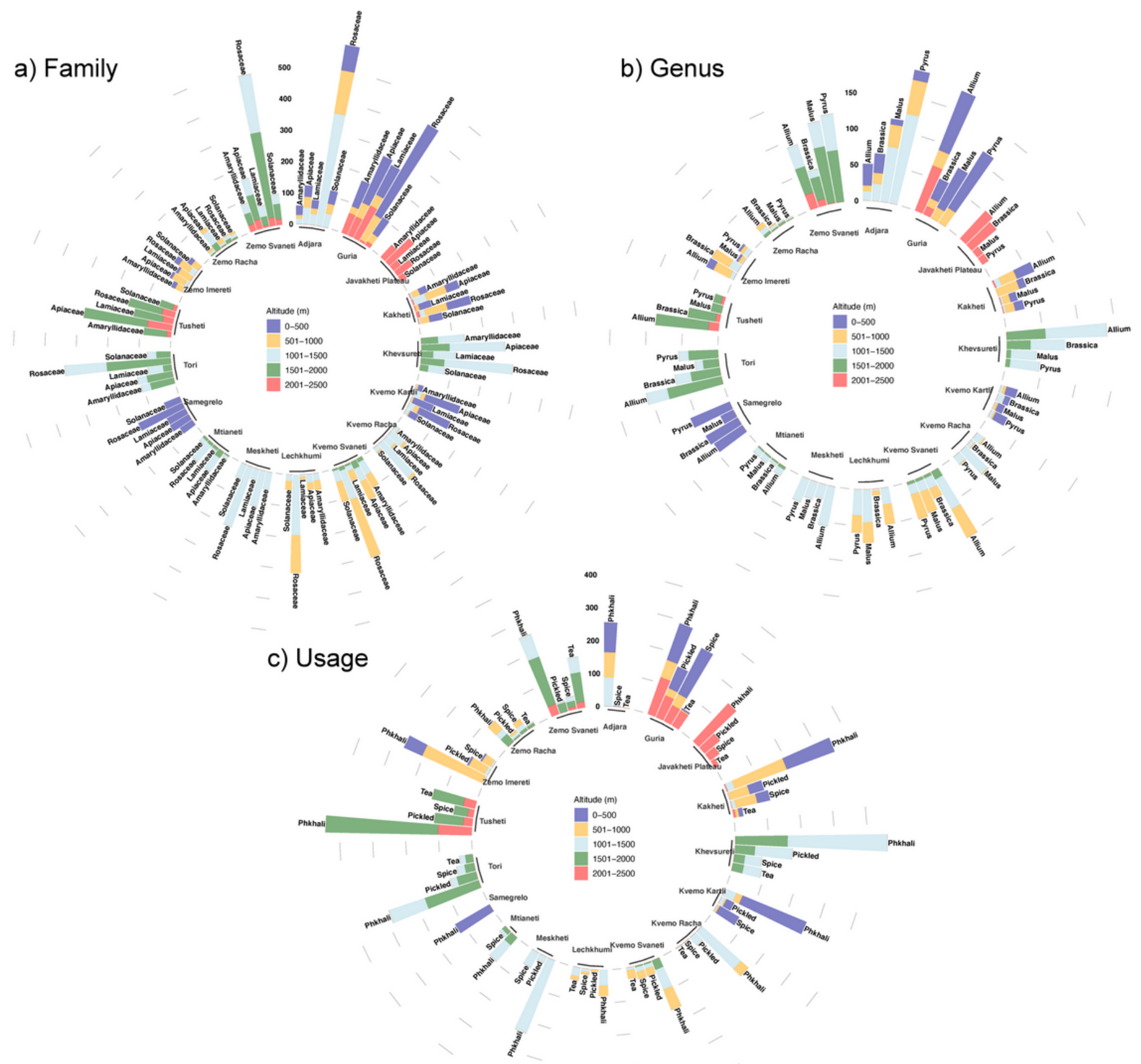

Figure 11

Absolute mention of families and genera by region and altitudinal distribution

\section{Supplementary Files}

This is a list of supplementary files associated with this preprint. Click to download.

- AppendixTable1.docx

- AppendixTable2.docx 
- AppendixTable3.docx

- AppendixTable4.docx

- AppendixTable5.docx

- AppendixTable6.docx

- AppendixTable7.docx

- AppendixTable8.docx

- Table1.pdf

- Table2.pdf

- Table3.pdf 